\title{
FLOOD MANAGEMENT BASED ON THE POTENTIAL URBAN CATCHMENTS CASE STUDY PADANG CITY
}

\author{
${ }^{*}$ Dwi Marsiska Driptufany ${ }^{12}$, Quinoza Guvil ${ }^{1}$, Desi Syafriani ${ }^{1}$, Dwi Arini ${ }^{1}$ \\ ${ }^{* 1}$ Department of Geodetic Engineering, Institute of Padang Technology (ITP) - Indonesia \\ ${ }^{2}$ Doctoral Program in Environmental Science, Universitas Negeri Padang - Indonesia \\ Email: dwimarsiska@itp.ac.id
}

*Corresponding Author, Received: March 8, 2021. Revised: March 21, 2021. Accepted: May 20, 2021

\begin{abstract}
The water catchment area also indirectly impacts on flood control for areas that are lower than it because rainwater does not fall to the lower areas but is absorbed as groundwater. Increased development of Padang City will be inversely proportional to the reduction in water catchment areas and become an area that is impermeable that makes rainwater stagnate on the surface and flood occurs. The development of remote sensing technology and geographic information systems has made it possible to study the spatial patterns of potential water catchment areas in a wide range, including mapping the potential of water catchment areas in Padang City. This study aims to analyze the condition of the availability of water catchment areas for controlling water management and flood disasters in Padang City based on data on spatial parameters such as rainfall data, slope, soil type maps, and land use obtained from Landsat 8 OLI imagery data. This study uses the scoring and overlay method with the Geographical Information System. The results show that the condition of the water catchment area in the western part of Padang City have been critical, reaching $18.29 \%$ of the total area of Padang City, this is due to land use that has undergone a change of function. If the water infiltration condition worsens (critical), it gives more opportunities for flooding and inundation. Thus the areas with the potential for water absorption which are categorized as critical and very critical in the research location can be said to be areas that are potentially prone to flooding and inundation, because the ground surface is no longer able to absorb water. Monitoring the potential of water catchment areas is one form of flood mitigation efforts.
\end{abstract}

\section{Keywords: Water Catchment Area, Flood, Geographic Information System, Spatial}

\section{INTRODUCTION}

The need for land as space in the development process continues to increase in order to improve community welfare. Land use has a spatial dimension related to land use patterns and a time dimension related to changes in land use patterns. Water catchment areas also indirectly have an impact on flood control for areas that are lower than them because rainwater does not fall to the lower areas but is absorbed as groundwater. This absorbed water will then become a water reserve in the dry season as well as a water supply for the area below it. Of course, if the water catchment area changes its function to an established cultivation area, the absorption of water into the soil will be hampered and worse, it will not be able to absorb water so that the water flows to the surface which can cause flooding and will reduce water reserves in the ground for urban activities. [1].

Changes in land use functions and climate change in line with an increase in the rate of surface water and a decrease in the quality of water infiltration into the soil. A decrease in the quantity of rainwater infiltration triggers an increase in the quantity of surface water and a decrease in land surface [2]. Land use change is the main cause behind the changing hydrological processes, ecosystem and environment in urban catchments [3].

The incidence of flooding in Padang City is increasing from year to year. Large quantities of rain falling and a short span of time in the built-up area causes a high volume of inundation and runoff. If all rainwater is channeled through existing rainwater channels (drainage channels) into rivers without being infiltrated into the ground, it will disrupt the balance of the water system and hydro ecosystem [4]. In general, flooding in Padang city is caused by the water flow and drainage that are unable to accommodate the water discharge so that the water overflows which will cause flooding. Flood has quite damaging effects on the affected area, including it will result in an increase in environmental disasters $[5,6]$. The 
surface of the city generally uses water-resistant materials, in built areas the use of building materials such as asphalt, cement, and concrete causes water flow and drainage to be unable to accommodate water discharge so that water overflows which will cause flooding. In addition, if an area is watertight, it will be flooded when it rains because the water is blocked on the surface and does not seep into the ground.

The increase in the development of Padang City will be inversely proportional to the reduction in air catchment areas and becoming an airtight area which causes rainwater to stagnate on the surface and cause flooding. Floods that submerge several urban villages in Padang City can cause various problems for public health [7] and even death [8], economic losses [9], and serious psychological disorders [10].

Hydrological models have the advantage of assessing the impact of spatial patterns on urban rainfall runoff processes at various spatial scales. Geophysical factors affecting watershed runoff, such as soil conditions, climate and land cover, can be easily configured by changing the input parameters in the hydrological model $[11,12]$. In addition, hydrological models provide a reductionist way of calculating the characteristics of various spatial scenarios in detail without considering environmental complexity [13-15]. Thus, spatial based analysis is needed to generalize specific hydrological processes, and thus provide guidance for future urban flood management efforts [16].

In addition, the development of remote sensing technology and geographic information systems has made it possible to study the spatial patterns of potential water catchment areas in a wide range $[17,18]$. The combination of remote sensing technology and geographic information systems is very useful for early detection, monitoring the patterns, distribution and trends of city microtemperatures and predicting the effects on urban and residential ecology as well as helping in the decision-making process on land use planning in Padang City.

Urban spatial patterns can promote the process of rainfall runoff in urban water catchments which are important for urban planning and flood management [19]. For example, the Geographical Information System can perform spatial data analysis and can be used as a decision making related to geography, including the problem of mapping the potential water catchment areas of Padang City.

This study aims to model the potential of water catchment areas for urban flood management in the Padang City based on spatial parameter data.

\section{RESEARCH METHODS}

\subsection{Study Area}

Padang City is a city with a fairly high rainfall and rainfall frequency. The city of Padang was chosen as the research location because the city of Padang is the provincial capital which is experiencing rapid development. The increase in the development of the city of Padang will be inversely proportional to the reduction in water catchment areas and becoming a watertight area which causes rainwater to stagnate on the surface and cause flooding.

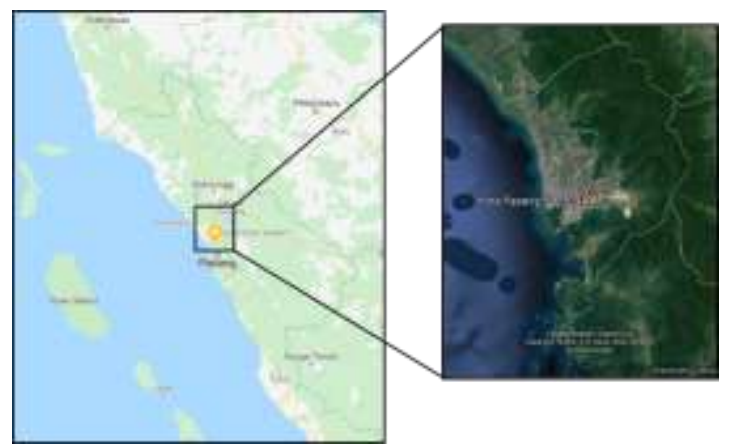

Fig.1. Study Area

\subsection{Data and Research Stages}

The data used in this study are LANDSAT 8 OLI imagery obtained from Earth Explorer USGS (http://earthexplorer.usgs.gov), soil type data, geological data, and slope data obtained from the Padang City BAPPEDA agency and rainfall data obtained from the Laboratory of Fluid Mechanics UNAND. LANDSAT 8 OLI Image Data is extracted to obtain actual land use data. The method used in this research is the scoring method and overlapping or overlay. Spatial analysis of water catchment zoning by overlaying spatial data. Determination of the potential zone of water catchment areas using a combination of spatial scoring and arithmetic methods.

The research stages began with the data collection process. Landsat Image Extraction The actual land use in this study was obtained through data extraction of Landsat 8 OLI imagery. The initial stage of the extraction process, namely radiometric correction, is an image correction due to radiometric errors or radiometric defects, namely errors in the form of shifting values or degrees of gray image elements (pixels) in the image, caused by optical system errors, due to interference of electromagnetic radiation energy in the atmosphere, and errors due to the influence of the sun's elevation angle.

The next stage is the process of image classification and interpretation using ENVI 5.1 software. This study uses the IIL model derived 
from Landsat 8 OLI imagery. IIL acts as an object generator source in the segmentation process. IIL is built through a layer stacking process [20]. The method used in the segmentation process is the Edge Method. This step is included in the Feature extraction - Example based classification process by including a scale level, namely the process of segmenting images that have the same color or texture. After entering the scale level, it is followed by region merging which basically aims to group the parts that have the same object in order to improve the quality of segmentation.

The next step is to test the accuracy of the interpretation results through field checking by measuring several coordinate points (sample areas) of land use / land cover. The United States Geological Survey (USGS) has determined a minimum level of classification accuracy or interpretation using remote sensing, which is less than $85 \%$ [21].

Rainfall maps are obtained from annual average rainfall data and data on the coordinates of the location of rainfall observation stations that represent the entire area of Padang City. Rainfall information is as follows: the amount of average monthly rainfall, the number of days of average rain in a month, and the average daily rainfall for a given month are needed to calculate the erosivity of the average monthly rainfall or the erosivity of the annual Bols or Lenvain). Long-term data are also needed, at least 10 years and preferably more than 20 years. Rainfall data is processed into spatial data using geostatistical interpolation methods.

The soil type map obtained is a soil type map covering the entire Padang City area obtained from secondary data (agency data). Soil type is very influential on the infiltration process or the level of soil infiltration when compared to the capacity of rainwater that falls directly on the ground does not exceed or is less than the infiltration capacity, so the rate of infiltration can be said to be the same as the intensity of rain. Peta jenis tanah dibuat dengan mengekstrak data DEM (Digital Elevation Model) Kota Padang. Data DEM diolah dengan metode interpolasi dan klasifikasi kelas lereng menjadi beberapa kelas kemiringan lereng yaitu: 0-8\% (datar), 8-15 (landai), 15-25\% (bergelombang), 25$40 \%$ (agak curam) dan $>40 \%$ (sangat curam) [22].

Classification of parameters of slope, soil type, rainfall, and land use is quoted from the Regulation of the Minister of Forestry of the Republic of Indonesia Number: P. 32/MenhutIi/2009 in the Critical Assessment of Infiltration Areas (Optional) on the Technique for
Determining the Classification of Infiltration Levels [23].

The overlay process is to combine two or more graphic data to obtain new graphic data that has a mapping unit (mapping unit). The result of the overlay will give you a new mapping unit (new map). The arithmetic method used in making a map of potential water catchment areas is the arithmetic method used in the overlay process of the potential water catchment area parameters in the form of a method of multiplying the score with the weight of each parameter of the potential water absorption area (infiltration).

The results of the water infiltration parameter scoring are used to fill in the attribute data of the parameters that determine the natural infiltration ability. The data that has been filled in with the dignity values are then overlaid using the intersect overlapping analysis method. The value of the infiltration ability interval uses the Sturgesss interval formula, which is to divide the highest data value and the lowest data value so that it matches the desired class, the Sturgess interval formula [24]:

$$
\begin{aligned}
& \mathrm{Ki}=(\mathrm{Xt}-\mathrm{Xr}) / \mathrm{k} \\
& \text { Information: } \\
& \mathrm{Ki}=\text { Interval Class } \\
& \mathrm{Xr}=\text { Lowest data } \\
& \mathrm{Xt}=\text { Highest Data } \\
& \mathrm{k}=\text { The number of classes desired }
\end{aligned}
$$

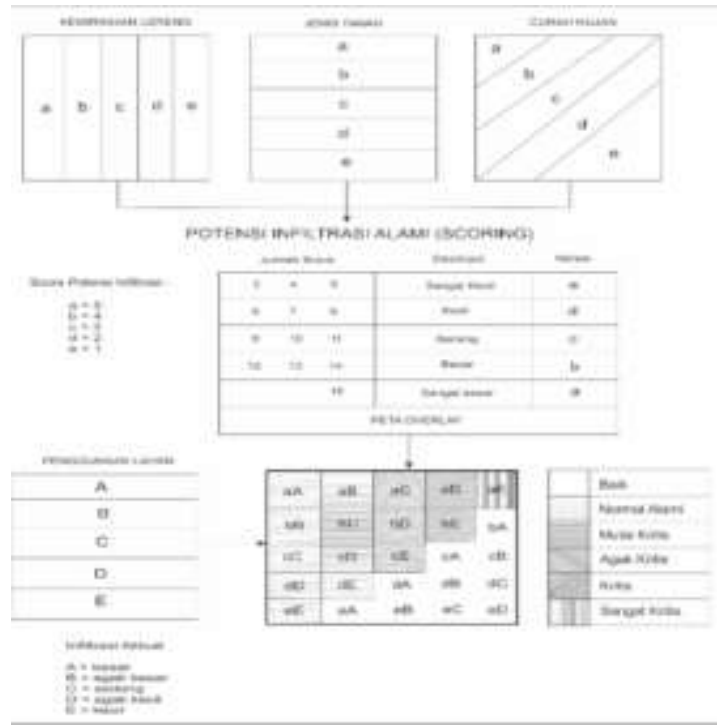

Fig.2. Preparation Assessment Model Approach Catchments [23,25]

The overlay process results from the natural infiltration ability of land use data using the 1998 Directorate General of Reforestation and Land Rehabilitation infiltration model, modified by Wahyuni, et al. (2017) as presented in Figure 2. 


\section{RESULTS AND DISCUSSION}

In this study, water infiltration is divided into 6 classes according to the Procedure for Preparing the Technical Plan for the Rehabilitation of Forests and Watershed Land (RTkRLHDAS), [26] that water catchment areas are divided into six classification criteria for water infiltration conditions ranging from good infiltration conditions. until the very critical condition. The explanation for each catchment area is as follows:

Table 1. Potential Condition of Actual Water Infiltration in Padang City

\begin{tabular}{clrr}
\hline No & \multicolumn{1}{c}{ Infiltration } & Are (Ha) & $\begin{array}{r}\text { Percentage } \\
(\%)\end{array}$ \\
\hline 1 & Good & 49011,004 & 69,79 \\
2 & Normal Natural & 4013,590 & 5,71 \\
3 & Start Critical & 1435,447 & 2,04 \\
4 & Somewhat Critical & 2234,946 & 3,18 \\
5 & Critical & 12848,143 & 18,29 \\
6 & Very Critial & 683,527 & 0,97 \\
\hline
\end{tabular}

The condition of the water catchment area with the largest area in the study area, namely an area of $69.79 \%$ of the area of the study area, is in good infiltration conditions, scattered in the eastern region of Padang City which is a mountainous area that has varying heights and is dominated by dense forest. This is followed by critical water infiltration, covering an area of $18.29 \%$ of the research area which is spread evenly in the western part of Padang City with a relatively flat to gentle slope and is dominated by the use of paddy fields and built-up land. Furthermore, normal natural water infiltration conditions have an area of $5.71 \%$ of the total area of the study area. The water infiltration condition is rather critical, covering an area of $3.18 \%$ of the total area of the study area. The condition of water infiltration is starting to be critical, covering an area of $2.04 \%$ of the total area of the study area. The water infiltration conditions with the smallest area in the study area, namely $0.97 \%$ of the total area of the study area, are in very critical water infiltration conditions which are in an area dominated by Organosol and Glei Humus soil types and dominated by the use of paddy fields, open land. (mining) and built-up land.

The results of mapping and identification of the actual conditions of the water catchment area based on land use in this research location indicate that the function of the water catchment area in Padang City is still good because most of the city is still dominated by forests. However, most of the water catchment areas in the western part of Padang City have been critical, reaching $18.29 \%$ of the total area of Padang City, this is due to land use that has undergone a change of function.

The map of potential water cactment areas in Padang City that can be seen on the map Fig.1 below.

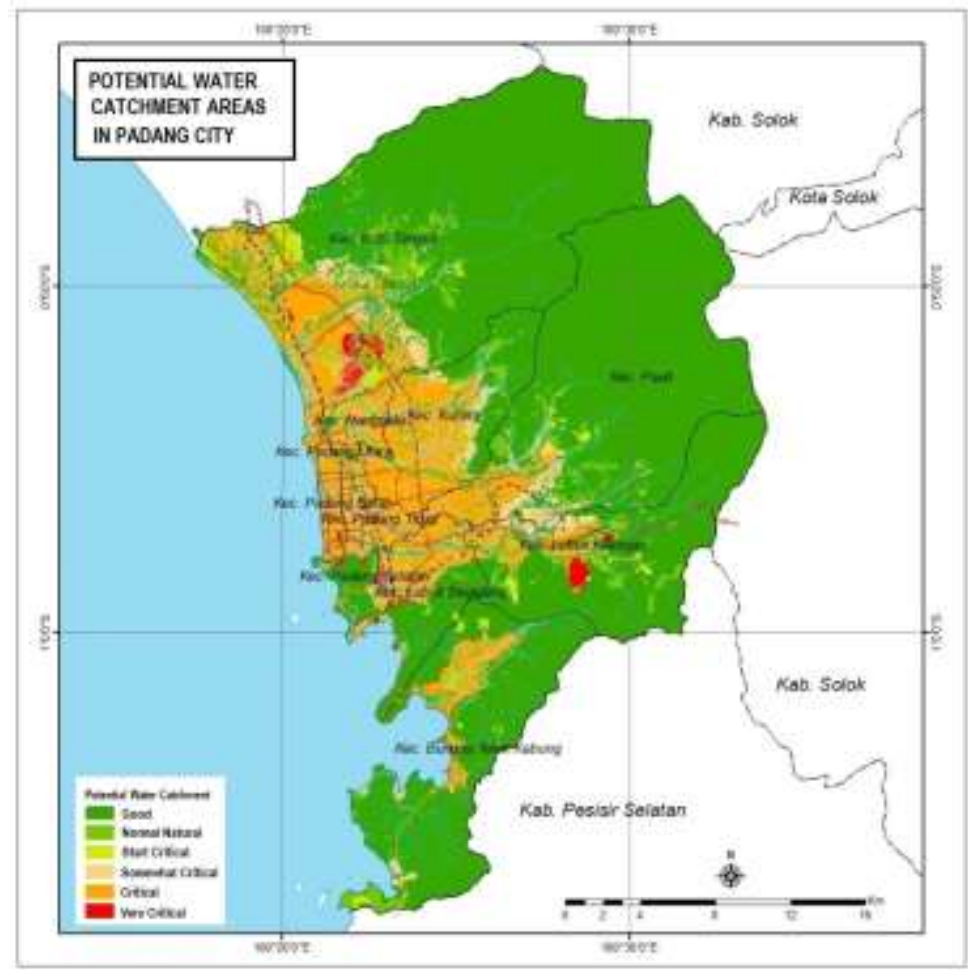

Fig.3 Map Potential Water Cactment Areas of Padang City 
Based on the research results, the area of potential for water absorption can be determined by using the Geographical Information System application. Whether or not the water infiltration of an area depends on the parameters of water infiltration. Areas that include good infiltration are areas that have a high total score according to the results of the overlay analysis. The better the infiltration of a parameter, the better the water infiltration of an area. In general, areas whose soil types have good infiltration have good infiltration. If the water infiltration condition worsens (critical), it gives more opportunities for flooding and inundation. Thus the areas with the potential for water absorption which are categorized as critical and very critical in the research location can be said to be areas that are potentially prone to flooding and inundation, because the ground surface is no longer able to absorb water.

Monitoring the potential of water catchment areas is one form of flood mitigation efforts. Disaster mitigation activities are part of disaster management activities that focus on reducing potential impacts and losses due to disasters $[5,6,27]$. The potential of water catchment areas can be used as a recommendation in urban spatial planning in flood control and urban water management.

\section{CONCLUSION}

The condition of the water catchment area with the largest area in the study area, which is $69.79 \%$ of the total area of the study area, is in good infiltration conditions scattered in the eastern region Padang City is a mountainous area that has varying heights and is dominated by dense forest. However, most of the water catchment areas in the western part of Padang City have been critical, reaching $18.29 \%$ of the total area of Padang City, this is due to land use that has undergone a change of function. If the water infiltration condition worsens (critical), it gives more opportunities for flooding and inundation. Thus the areas with the potential for water absorption which are categorized as critical and very critical in the research location can be said to be areas that are potentially prone to flooding and inundation, because the ground surface is no longer able to absorb water. Monitoring the potential of water catchment areas is one form of flood mitigation efforts.

\section{ACKNOWLEDGEMENTS}

This writing this literature reviews can be carried out smoothly, because of the help and cooperation of various parties. Therefore, the author would like to thank Prof. Dr. Dedi Hermon,
MP as the Deputy Director II of the Postgraduate Universitas Negeri (also chairman of the course of disaster risk management, disaster mitigation, and Geography Information Systems/GIS in the Doctoral Program in Environmental Science, Universitas Negeri Padang) who have provided the opportunity and time to sharpen the academic ability my, especially in the field of disaster environmental.

\section{REFERENCES}

[1] Putranto TT, Hadiyanto H, Hati AC. Study of Determination of Infiltration Wells as an Effort to Control Floods in Pekalongan City Based on Geographical Information Systems. Pekalongan City Research and Development Journal. 2021 Jan 8; 19

[2] Yulianto F, Suwarsono S, Maulana T, Khomarudin MR. Analysis of the dynamics of coastal landform change based on the integration of remote sensing and GIS techniques: Implications for tidal flooding impact in Pekalongan, Central Java, Indonesia. Quaestiones Geographicae. 2019 Sep 30;38(3):17-29.

[3] Zope PE, Eldho TI, Jothiprakash V. Impacts of urbanization on flooding of a coastal urban catchment: a case study of Mumbai City, India. Natural Hazards. 2015 Jan 1;75(1):887-908.

[4] Muliawati DN. Planning for the implementation of an environmentally sound drainage system (ecodrainage) using infiltration wells in the Rungkut area (Doctoral dissertation, Sepuluh Nopember Institute of Technology).

[5] Hermon, D. (2019). Mitigation and Adaptation:Disaster of Climate Change. Sara Book Publication. India.

[6] Hermon, D. (2019). Land Stability Model for Sustainable Spatial Planning in Padang CityIndonesia based on Landslide Disaster. Journal of Geography and Earth Sciences, 7(1), 19-26.

[7] Mitrović VL, O’Mathúna DP, Nola IA. Ethics and floods: a systematic review. Disaster medicine and public health preparedness. 2019 Aug;13(4):81728.

[8] George P. Health impacts of floods. Prehospital and disaster medicine. $2011 \mathrm{Apr} ; 26(2): 137$ -

[9] Parida Y. Economic impact of floods in the Indian states. Environment and Development Economics. 2020 Jun;25(3):267-90.

[10] Yoda T, Yokoyama K, Suzuki H, Hirao T. Relationship between long-term flooding and serious mental illness after the 2011 flood in Thailand. Disaster medicine and public health preparedness. 2017 Jun 1;11(3):300-4.

[11] Yang, G.; Bowling, L.C.; Cherkauer, K.A.; Pijanowski, B.C. The impact of urban development on hydrologic regime from catchment to basin scales. Landsc. Urban Plan. 2011, 103, 237-247.

[12] Dams, J.; Dujardin, J.; Reggers, R.; Bashir, I.; Canters, F.; Batelaan, O. Mapping impervious surface change from remote sensing for hydrological modeling. J. Hydrol. 2013, 84-95. 
[13] Faulkner, D.S.; Francis, O.; Lamb, R. Greenfield run off and flood estimation on small catchments. J. Flood Risk Manag. 2012, 5, 81-90.

[14] Grimaldi, S.; Petroselli, A.; Romano, N. CurveNumber/Green-Ampt mixed procedure for streamflow predictions in ungauged basins: Parameter sensitivity analysis. Hydrol. Processes 2013, 27, 1265-1275.

[15] Grimaldi, S.; Petroselli, A. Do we still need the Rational Formula? An alternative empirical procedure for peak discharge estimation in small and ungauged basins. Hydrol. Sci. J. 2014, 60, 6777

[16] Zoppou, C. Review of urban storm water models. Environ. Model. Softw. 2001, 16, 195-231.

[17] Guvil Q, Driptufany DM, Ramadhan S. Analisis Potensi Daerah Resapan Air Kota Padang. InSeminar Nasional Geomatika 2019 Feb 15 (Vol. 3, pp. 671-680).

[18] Driptufany DM, Guvil Q, Ramadhan S. Aplikasi Sistem Informasi Geografis Untuk Estimasi Sebaran Daerah Potensi Resapan Air Kota Padang. Jurnal Momentum ISSN 1693-752X. 2019 Feb 1;21(1):8-14.

[19] Yao L, Chen L, Wei W. Exploring the linkage between urban flood risk and spatial patterns in small urbanized catchments of Beijing, China. International journal of environmental research and public health. 2017 Mar;14(3):239.

[20] Mather P, Tso B. Classification methods for remotely sensed data. CRC press; 2016 Apr 19.

[21] Sampurno RM, Thoriq A. Klasifikasi tutupan lahan menggunakan citra landsat 8 operational land imager (OLI) di Kabupaten Sumedang (land cover classification using landsat 8 operational land imager (OLI) data in Sumedang Regency). Jurnal Teknotan Vol. 2016 Nov;10(2).

[22] Matondang JP, Kahar S, Sasmito B. Analisis Zonasi Daerah Rentan Banjir Dengan Pemanfaatan Sistem Informasi Geografis (Studi Kasus: Kota Kendal dan Sekitarnya). Jurnal Geodesi Undip. 2013 Apr 15;2(2).

[23] Peraturan Menteri Kehutanan Republik Indonesia No: P.32/Menhut-II/2009 tentang Tata Cara Penyusunan Rencana Teknik Rehabilitasi Hutan dan Lahan Daerah Aliran Sungai (RTkRHL-DAS)

[24] Hendriana KI, Yasa IG, Kesiman MW, Sunarya IM. Sistem Informasi Geografis Penentuan Wilayah Rawan Banjir di Kabupaten Buleleng. KARMAPATI (Kumpulan Artikel Mahasiswa Pendidikan Teknik Informatika). 2013 Jul 31;2(5):608-16.

[25] Wahyuni W, Arsyad U, Bachtiar B, Irfan M. Identifikasi Daerah Resapan Air di Sub Daerah Aliran Sungai Malino Hulu Daerah Aliran Sungai Jeneberang Kabupaten Gowa. Jurnal Hutan dan Masyarakat. 2017 Dec 30;9(2):93-104.

[26] Wibowo M. Model Penetuan Kawasan Resapan Air untuk Perencanaan Tata Ruang Berwawasan Lingkungan. Jurnal Hidrosfir Indonesia. 2006;1(1).

[27] Hermon D. Climate Change Mitigation. Jakarta. 2017 